\section{$018-019$}

\section{Noticias y comentarios}

\section{PH44 - Julio 2003}
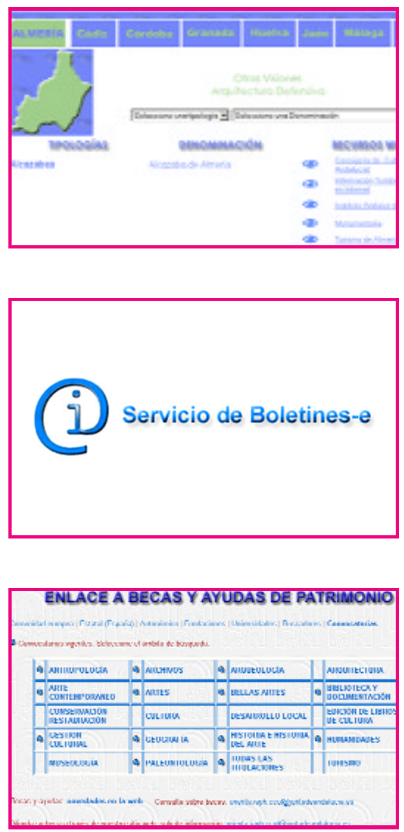

Nuevas cuentas del Centro de Intervención del IAPH

Los Departamentos de Investigación, Análisis y Tratamiento del Centro de Intervención del IAPH disponen de nuevas cuentas de correo-e que pueden consultarse, junto con las del resto del Instituto, en la dirección

www.juntadeandalucia.es/ cultura/iaph/sede/ sedeweb/index.html

\title{
Novedades de la Sede Web marzo-mayo 2003
}

A continuación se muestran las novedades en el Servidor Web del IAPH entre marzo y mayo de 2003 (véase recuadro adjunto), entre las que destacan el nuevo Servicio de Alerta Informativa de Boletines Electrónicos y el producto Otras Visiones.

Incorporaciones de boletines en el servicio de alerta informativa

Desde el pasado otoño, el Centro de Documentación del IAPH ha ido añadiendo paulatinamente a su Servicio de Alerta nuevos boletines electrónicos de información. A los iniciales "Novedades de la Biblioteca" y "Novedades del Servidor Web" (véase PH 40-41, p. 260), se han sumado en los últimos meses el boletín de "Novedades de la Fototeca" y el "Sumario de boletines oficiales".

El producto "Novedades de la Fototeca" acerca cada trimestre la información gráfica recientemente incorporada a la Fototeca del IAPH, mediante su catalogación en la base de datos Gráfica. La información se presenta en una ficha-resumen, que agrupa varios documentos gráficos, atendiendo a diversos criterios: tipología de soportes, ámbito geográfico o tipología de bienes culturales. Los documentos referenciados se encuentran disponibles para su visionado en la Sala de Consulta de la Biblioteca del IAPH.

A través del "Sumario de Boletines Oficiales" se accede periódicamente a los índices del BOE y del BOJA publicados en la semana inmediatamente anterior a su envío. Los enlaces recogidos permiten a los usuarios visualizar el texto completo de las publicaciones oficiales.

En todos los casos, el acceso se realiza mediante suscripción a través de un formulario electrónico de alta, disponible junto con información complementaria en

<http://www.juntadeandalucia.es/cultura/iaph/ documentacion/serv_infor/boletinesinformacion/ presentacion.html>

De forma inminente, se tiene prevista la incorporación de nuevos Boletines de Información relativos a publicaciones, cursos y becas y ayudas del IAPH.

Nuevo producto: Otras Visiones

Dentro del apartado Información PHA, en <http://www.juntadeandalucia.es/cultura/ iaph/infopha/07ovisi/index.html>), Otras Visiones recoge la información disponible en otras sedes Web sobre los bienes culturales andaluces.

A través de búsquedas especializadas, se analizan y seleccionan los recursos existentes sobre distintas tipologías del Patrimonio, previamente escogidas por su interés y representación en la Red.
El Mapa Web de Bienes Culturales en Andalucia permite una navegación geográfica por provincias a los enlaces escogidos. Además de este mapa, se facilitarán otras opciones de acceso a la información: Productos Web de Bienes Culturales en Andalucia, que recopilará y unificará la información de los bienes que tengan mayor representación en Internet; y Recursos Web de Interés, donde se mostrarán otras informaciones de interés general sobre la tipología analizada: artículos, bibliografía especializada, cursos, publicaciones, legislación, noticias e imágenes, entre otros.

En una primera fase, se ha tratado el tema de la Arquitectura Defensiva en Andalucia, con unas 250 sedes analizadas. Progresivamente, se irán incorporando otras tipologías.

En mayo:

$>$ Estadisticas del Servidor Web correspondientes a abril de 2003.

$>$ Actualización del Calendario de Actividades de Formación en España y otros países.

$>$ Nuevas convocatorias de becas y ayudas en el ámbito de la cultura y el patrimonio en otros organismos e instituciones.

$>$ Nuevas Jornadas Técnicas, en colaboración con el Colegio Oficial de Doctores y Licenciados en Bellas Artes de Andalucia.

$>$ Nuevo boletín de Adquisiciones del Fondo Gráfico (febrero-abril 2003)

En abril:

$>$ Estadisticas del Servidor Web correspondiente a marzo de 2003.

$>$ Actualización del Calendario de Actividades de Formación en España y otros paises.

$>$ Encuesta de evaluación de Demandas Puntuales de Información.

> Boletin PH 43 (abril 2003).

$>$ Encuesta de valoración de la serie Cuadernos y Cuadernos Técnicos.

> Actualización del apartado Textos-e en Información PHA (Boletín PH 43 - abril 2003).

En marzo:

$>$ Estadísticas del Servidor Web correspondiente a febrero de 2003.

$>$ Actualización del Calendario de Actividades de Formación en España y otros países.

$>$ Aviso de suspensión del curso "Tratamientos actuales de conservación restauración de pintura sobre tabla".

$>$ Aviso de apertura de la preinscripción para el curso:

"Cartografía, topografía y conservación en cuevas y abrigos con yacimientos arqueológicos".

$>$ Nuevas convocatorias de becas y ayudas en el ámbito de la cultura y el patrimonio en otros organismos e instituciones.

$>$ Producto Otras Visiones.

$>$ Boletines electrónicos de alerta informativa.

\section{Isabel Ortega Vaquero}

Susana Limón Rodríguez

Centro de Documentación del IAPH 